\title{
A MESHLESS MODEL OF ELECTROMAGNETIC BRAKING FOR THE CONTINUOUS CASTING OF STEEL
}

\author{
BREZMREŽNI MODEL ELEKTROMAGNETNEGA ZAVIRANJA PRI \\ KONTINUIRANEM ULIVANJU JEKLA
}

\author{
Katarina Mramor'1, Robert Vertnik ${ }^{2}$, Božidar Šarler ${ }^{1,2}$ \\ ${ }^{1}$ University of Nova Gorica, Vipavska 13, 5000 Nova Gorica, Slovenia \\ ${ }^{2}$ Institute of Metals and Technology, Lepi pot 11, 1000 Ljubljana, Slovenia \\ katarina.mramor@ung.si,bozidar.sarler@imt.si,robert.vertnik@imt.si
}

Prejem rokopisa - received: 2015-04-21; sprejem za objavo - accepted for publication: 2015-06-08

doi:10.17222/mit.2015.084

The application of magnetohydrodynamics in the continuous casting of steel enables improved control of the quality of the strand. The most common applications are electromagnetic braking (EMBR) and electromagnetic stirring (EMS). The former slows the flow by applying a static magnetic field and thus improves the steel flow pattern, reduces the velocity and the turbulence of the flow, increases the cleanliness of the material, improves the surface quality and reduces the number of inclusions, whereas the latter stirs the flow by applying an alternating magnetic field and thus improves the quality of the strand, reduces the surface and subsurface defects, enhances the solidification and reduces the number of breakouts.

In this contribution EMBR in a continuous-casting process is considered. The local radial basis function collocation method (LRBFCM) is used for the solution of coupled mass, energy, turbulent fluid flow, species and magnetic field equations. The explicit Euler time-stepping scheme and the collocation with multiquadrics radial basis functions on the five-noded overlapping influence domains are used to obtain the solution of the partial differential equations. The Abe-Kondoh-Nagano low Reynolds turbulence model is used to describe the turbulent fluid flow, whereas the fractional step method is used to solve the pressurevelocity coupling. The method has been thoroughly tested in several test cases. In the present article the influence of the application of electromagnetic braking on the macro-segregation in the continuous-casting process for carbon steel is presented.

Keywords: LRBFCM, continuous casting of steel, turbulent flow, magnetic field, macro-segregation

Uporaba magnetohidrodinamike pri kontinuiranem ulivanju jekla omogoča izboljšano kontrolo kakovosti žile. Najpogostejši aplikaciji sta elektromagnetno zaviranje (EMBR) in elektromagnetno mešanje (EMS). Prva zavira tok z uporabo statičnega magnetnega polja in tako izboljša tokovni vzorec jekla, zmanjša hitrost in turbulenco toka, poveča čistost materiala, izboljša kvaliteto površine in zmanjša število vključkov, medtem ko druga meša tok z uporabo izmeničnega magnetnega polja in tako izboljša kvaliteto žile, zmanjša nepravilnosti na površini in pod njo, pospeši strjevanje in zmanjša število prodorov.

$\mathrm{V}$ tem prispevku je obravnavano EMBR pri kontinuiranem ulivanju jekla. Lokalna kolokacijska metoda $\mathrm{z}$ radialnimi baznimi funkcijami (LRBFCM) je uporabljena za reševanje sklopljenih enačb za maso, energijo, turbulenten tok tekočine, koncentracijo sestavin in magnetno polje. Eksplicitna Euler-jeva časovna shema in kolokacija z multikvadričnimi radialnimi baznimi funkcijami na pettočkovnih prekrivajočih se poddomenah sta uporabljeni za rešitev parcialnih diferencialnih enačb. Abe-KondohNaganov turbuletni model za nizka Reynolds-ova števila je uporabljen za opis turbulentnega toka, medtem ko je metoda delnih korakov uporabljena za rešitev tlačno-hitrostne sklopitve. Metoda je bila izdatno preizkušena na več preizkusnih primerih. $\mathrm{V}$ tem članku je predstavljen vpliv elektromagnetnega zaviranja na makroizcejanje pri kontinuiranem ulivanju ogljičnega jekla.

Ključne besede: LRBFCM, kontinuirano ulivanje jekla, turbulentni tok, magnetno polje, makroizcejanje

\section{INTRODUCTION}

In the manufacturing of steel, ${ }^{1}$ which has in recent years greatly expanded, continuous casting is one of the most common processes in steel production. ${ }^{2}$ The demand for cast steel of high quality fuels the need to further improve the casting process. One way to do that is to introduce either a static or an alternating electromagnetic (EM) field. In general, EM devices in the continuous casting of steel are divided into electromagnetic brakers (EMBR), which use a direct current to produce a static EM field, and into electromagnetic stirrers, which use an alternating current to produce an alternating magnetic field. The EM force, which is a result of the applied magnetic field in both cases, affects the velocity, temperature and concentration fields. By adjusting the magnetic field, the amount of defects, inclusions and air bubbles in the material can be significantly reduced. In the present contribution, the application of an EMBR system and its effects on velocity, temperature and concentration fields are presented.

The quality of the final product depends on the magnitudes of velocity, temperature, concentration and magnetic fields. In the continuous-casting process the velocity, temperature, concentration and magnetic fields are difficult, if not impossible, to measure. The numerical models are therefore applied in order to help us better understand and further improve the process. The problem under consideration has already been considered with several different numerical models, among which are the Finite Volume Method (FVM), ${ }^{3-8}$ the Finite Element Method (FEM), ${ }^{9}$ and some more advanced meshless methods, like the Local Radial Basis Function 
Collocation Method (LRBFCM) ${ }^{10}$ which is used in the present case as well. The purpose of this article is to present the results obtained for the application of EMBR in the CC process for carbon steel. The results are presented with and without magnetic field for the velocity, temperature and concentration fields.

\section{GOVERNING EQUATIONS}

The system of governing equations that describes the heat transfer, turbulent fluid flow, species concentration, and magnetic field in the continuous casting of steel, is based on the Reynolds time-averaging approach for modeling the turbulent flow ${ }^{11}$ and mixture continuum formulation, first introduced by Bennon and Incropera. ${ }^{12}$ Our model consists of six time-averaged equations:

$$
\begin{gathered}
\nabla \cdot \mathbf{v}=0 \\
\frac{\partial(\rho \mathbf{v})}{\partial t}+\nabla \cdot(\rho \mathbf{v v})=-\nabla p+\nabla\left[\left(\mu_{\mathrm{L}}+\mu_{l} \frac{\rho}{\rho_{\mathrm{L}}}\right)\left(\nabla \mathbf{v}+(\nabla \mathbf{v})^{T}\right)\right]- \\
-\frac{2}{3} \nabla(\rho k)-\mu_{\mathrm{L}} \frac{K_{0}\left(1-f_{\mathrm{L}}\right)^{2}}{f_{\mathrm{L}}^{3}}\left(\mathbf{v}-\mathbf{v}_{\mathrm{S}}\right)+ \\
+\rho \mathbf{g}\left(\beta_{\mathrm{T}}\left(T-T_{\text {ref }}\right)+\beta_{\mathrm{C}}\left(C-C_{r e f}\right)\right)+\mathbf{j} \times \mathbf{B}
\end{gathered}
$$

2)

$$
\begin{aligned}
& \frac{\partial(\rho h)}{\partial t}+\nabla \cdot(\rho \mathbf{v} h)=\nabla \cdot(\lambda \nabla T)+ \\
& +\nabla \cdot\left(\rho f_{\mathrm{S}}\left(h_{\mathrm{L}}-h_{\mathrm{S}}\right)\left(\mathbf{v}-\mathbf{v}_{\mathrm{S}}\right)\right)+\nabla\left(f_{\mathrm{L}} \frac{\rho_{\mathrm{L}} v_{\mathrm{t}}}{\sigma_{\mathrm{t}}} \nabla h_{\mathrm{L}}\right)+\frac{|\mathbf{j}|^{2}}{\sigma} \\
& \frac{\partial(\rho C)}{\partial t}+\nabla \cdot(\rho C \mathbf{v})=\nabla \cdot\left(\rho f_{\mathrm{S}} D_{\mathrm{S}} \nabla C_{\mathrm{S}}+\rho f_{\mathrm{L}} D_{\mathrm{L}} \nabla C_{\mathrm{L}}\right)+ \\
& +\nabla \cdot\left(\rho\left(C_{\mathrm{L}}-C\right)\left(\mathbf{v}-\mathbf{v}_{\mathrm{S}}\right)\right)+\nabla\left(\frac{f_{\mathrm{L}} \mu_{\mathrm{t}}}{\sigma_{\mathrm{C}}} \nabla C_{\mathrm{L}}\right) \\
& \frac{\partial(\rho k)}{\partial t}+\nabla \cdot(\rho \mathbf{v} k)=\nabla \cdot\left[\left(\mu_{\mathrm{L}} \frac{\rho}{\rho_{\mathrm{L}}}+\frac{\mu_{\mathrm{t}}}{\sigma_{\mathrm{k}}}\right) \nabla k\right]+ \\
& +P_{\mathrm{k}}+G_{\mathrm{k}}-\rho \varepsilon-\rho D_{\mathrm{k}-\varepsilon}+\mu_{\mathrm{L}} \frac{K_{0}\left(1-f_{\mathrm{L}}\right)^{2}}{f_{\mathrm{L}}^{3}} \frac{\rho}{\rho_{\mathrm{L}}} k \\
& \frac{\partial(\rho \varepsilon)}{\partial t}+\nabla \cdot(\rho \mathbf{v} \varepsilon)=\nabla \cdot\left[\left(\mu_{\mathrm{L}} \frac{\rho}{\rho_{\mathrm{L}}}+\frac{\mu_{\mathrm{t}}}{\sigma_{\varepsilon}}\right) \nabla \varepsilon\right]+\rho E_{\mathrm{k}-\varepsilon}- \\
& -\mu_{\mathrm{L}} \frac{K_{0}\left(1-f_{\mathrm{L}}\right)^{2}}{f_{\mathrm{L}}^{3}} \varepsilon+\left[c_{1 \varepsilon} f_{1}\left(P_{\mathrm{k}}+c_{3 \varepsilon} G_{\mathrm{k}}\right)-c_{2 \varepsilon} f_{2} \rho\right] \frac{\varepsilon}{k}
\end{aligned}
$$

Where $\mathbf{v}$ is the velocity of the mixture, $\rho=\rho_{\mathrm{S}}=\rho_{\mathrm{L}}$ is the density (assumed to be constant and equal in both phases). $t$ stands for time and $p$ for pressure. $\mu_{\mathrm{t}}$ is the turbulent viscosity and $\mu_{\mathrm{L}}$ is the dynamic viscosity, $k$ represents the turbulent kinetic energy and $K_{0}$ is the permeability constant. $\mathbf{v}_{\mathrm{S}}, \beta_{\mathrm{T}}, \beta_{\mathrm{C}}, \mathbf{g}, T, T_{\mathrm{ref}}, C$, and $C_{\text {ref }}$ represent the velocity of the solid phase, the thermal expansion coefficient, the solute expansion coefficient, the gravitational acceleration, the temperature, the refe- rence temperature, the species concentration and the reference species concentration, respectively. $\mathbf{j} \times \mathbf{B}$ stands for the Lorentz force, $h$ for the enthalpy, and $\lambda$ for the thermal conductivity. $f_{\mathrm{S}}, f_{\mathrm{L}}, h_{\mathrm{S}}$, and $h_{\mathrm{L}}$ represent the solid volume fraction, the liquid volume fraction, the enthalpy of the solid phase and the enthalpy of the liquid phase, $v_{\mathrm{t}}$ is the turbulent kinematic viscosity and $\sigma$ is the electrical conductivity. $D_{\mathrm{S}}$, and $D_{\mathrm{L}}$ are diffusion coefficients for the solid and liquid phases, respectively. $\varepsilon$ stands for the dissipation rate, $\sigma_{\mathrm{t}}, \sigma_{\mathrm{C}}, \sigma_{\mathrm{k}}, \sigma_{\varepsilon}, c_{1 \varepsilon}, f_{1}, c_{2 \varepsilon}$ and $f_{2}$ are closure coefficients. $P_{\mathrm{k}}, G_{\mathrm{k}}, D_{\mathrm{k}-\varepsilon}$, and $E_{\mathrm{k}-\varepsilon}$ are the shear production of turbulent kinetic energy, the generation of turbulence due to the buoyancy force, the source term in the $k$ equation and the source term in the $\varepsilon$ equation, respectively. In this contribution, only the porous zone is considered and is modelled using Darcy's law and the Kozeny-Carman relation. The closure relations, defined by Abe-Kondoh-Nagano, ${ }^{13}$ are used to set the turbulence closures. A detailed description of the closure coefficients, source terms and damping functions are given in the paper of Šarler et al. ${ }^{14}$ The Lorentz force is defined as:

$$
\mathbf{F}_{\mathrm{m}}=\mathbf{j} \times \mathbf{B}
$$

where $\mathbf{j}$ and $\mathbf{B}$ are the current density and the magnetic flux density. The Maxwell's equations are used to calculate the current density:

$$
\mathbf{j}=\sigma(-\nabla \emptyset+\mathbf{v} \times \mathbf{B})
$$

where $\varnothing$ is the fluid's electric potential. The assumption of a low magnetic Reynold's number $\left(\operatorname{Re}_{\mathrm{m}}<<1\right)$ is made.

\subsection{Boundary and initial conditions}

The governing equations for velocity, species concentration and temperature in the continuous-casting process

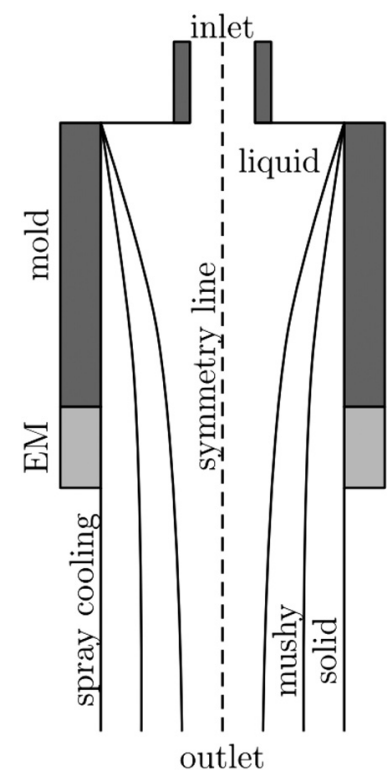

Figure 1: Simplified 2D model for continuous casting of steel Slika 1: Poenostavljen 2D-model za kontiunirano ulivanje jekla 


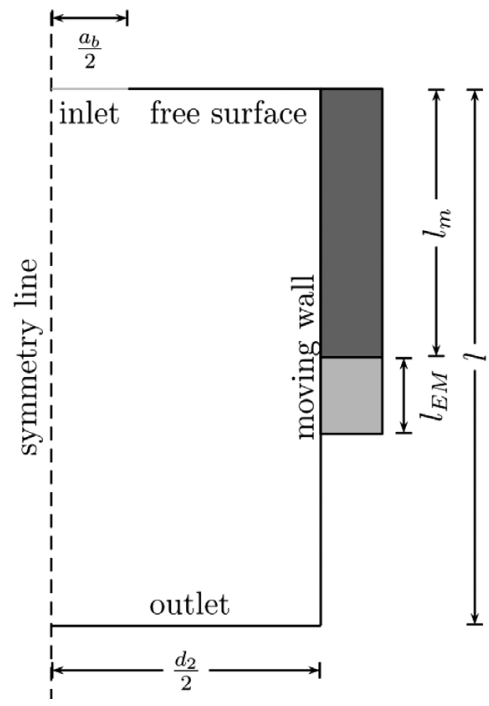

Figure 2: Computational domain scheme Slika 2: Shema računske domene

are strongly coupled. Although the coupling between the magnetic field and the rest of the governing equations is weak, it is still very important for the solution to the problem of how the initial and boundary conditions are chosen. In present case, five different boundaries are chosen: inlet, free surface, wall, outlet and symmetry. The model of the domain is presented in Figure 1, the computational domain is depicted in Figure 2, and the initial and boundary conditions are given in Figure 3 .

\section{SOLUTION PROCEDURE}

The explicit Euler time stepping and LRBFCM are used to solve the governing equations of the EMBR in the continuous-casting process. The pressure-velocity coupling is solved with the Fractional Step Method (FSM). ${ }^{15}$

The first step in the solution procedure is the calculation of the initial Lorentz force (Equation (7)). The procedure begins by solving the Poisson's equation for electric potential:

$$
\nabla^{2} \emptyset=\mathbf{v} \times \mathbf{B}
$$

the solution of which is then inserted into Equation (7). The Lorentz force is inserted into the equation for the intermediate velocity $\mathbf{v}^{*}$, which is calculated from the momentum equation by omitting the pressure-gradient term. The pressure is then calculated from the Poisson's equation by solving the pressure sparse matrix. ${ }^{14}$ The calculated pressure gradient is then used to correct the intermediate velocities of the final velocity field. After the solution of the velocity field, the equations for turbulent kinetic energy and dissipation rate are solved. This is followed by the solution of the enthalpy and species concentration equations. The enthalpy-temperature $^{14}$ constitutive relation is used to calculate the temperature from the enthalpy. Finally, the turbulent viscosity, velocity, temperature, species concentration, turbulent kinetic energy and dissipation rate are updated and the solution is ready for the next step.

The spatial discretization is solved using LRBFCM by constructing the approximation function $\theta$, that is represented on each of the subdomains as a linear combination of the radial basis functions (RBFs) as:

$$
\theta\left({ }_{l} \mathbf{p}_{n}\right)=\sum_{i=1}^{M}{ }_{l} \psi_{i}\left({ }_{l} \mathbf{p}_{n}\right)_{l} \alpha_{i}
$$

where $M, \imath \alpha_{i}$, and $n \psi_{i}$ represent a number of shape functions, an expansion coefficient, and RBF shape functions, centred at points $l \mathbf{p}_{n}$, respectively. The most commonly used RBFs are Multiquadric $\mathrm{RBF}^{16,17}$ :

$$
{ }_{l} \psi_{i}(\mathbf{p})=\sqrt{{ }_{l} r_{i}^{2}(\mathbf{p})+c^{2}}
$$

where $c$ stands for a dimensionless shape parameter, which is in our case set to 32 , and:

$$
{ }_{l} r_{i}(\mathbf{p})=\sqrt{\left(\frac{x-x_{i}}{{ }_{l} x_{i \max }}\right)^{2}+\left(\frac{y-y_{i}}{{ }_{l} y_{i \max }}\right)^{2}}
$$

is scaled by $x_{i \max }$, and $y_{i \max }$, the scaling parameters in the subdomains in the $x$ and $y$ directions, respectively (Figure 3).

A subdomain consists of the ${ }_{l} M-1$ nodes nearest to the node ${ }_{l} \mathbf{p}_{n}$ and is formed around each of the calculation points. In this contribution, five-nodded overlapping subdomains are used. A linear system of equations is obtained by considering the collocation condition:

$$
{ }_{l} \theta\left({ }_{l} \mathbf{p}_{n}\right)=\theta_{i(l, n)}
$$

To construct the Partial Differential Equation (PDE) derivatives, originating from the governing equations, the first and the second derivatives of the function $\theta(\mathbf{p})$ have to be calculated:

$$
\frac{\partial^{j}}{\partial \chi^{j}{ }_{l}} \theta(\mathbf{p})=\sum_{i=1}^{M} \frac{\partial^{j}}{\partial \chi^{j}{ }_{l}} \psi_{i}(\mathbf{p})_{l} \alpha_{i}
$$

where the index $j$ is used to denote the order of the derivative and $\chi=x, y$. A detailed explanation of the solution procedure is given in. ${ }^{18,19}$ The discretization scheme is shown in Figure 3.

\section{RESULTS}

The numerical procedure has so far been tested on the following benchmark test cases: lid driven cavity, natural convection in a cavity with a magnetic field, and a backward facing step with a transverse magnetic field and a test case for a simplified magnetic field in the continuous-casting process. As the results in all of the test cases are in good agreement with the reference results, both those calculated with the commercial code and those obtained from the literature, the method is now applied to the electromagnetic braking problem for the continuous casting of steel. The results of the EMBR 


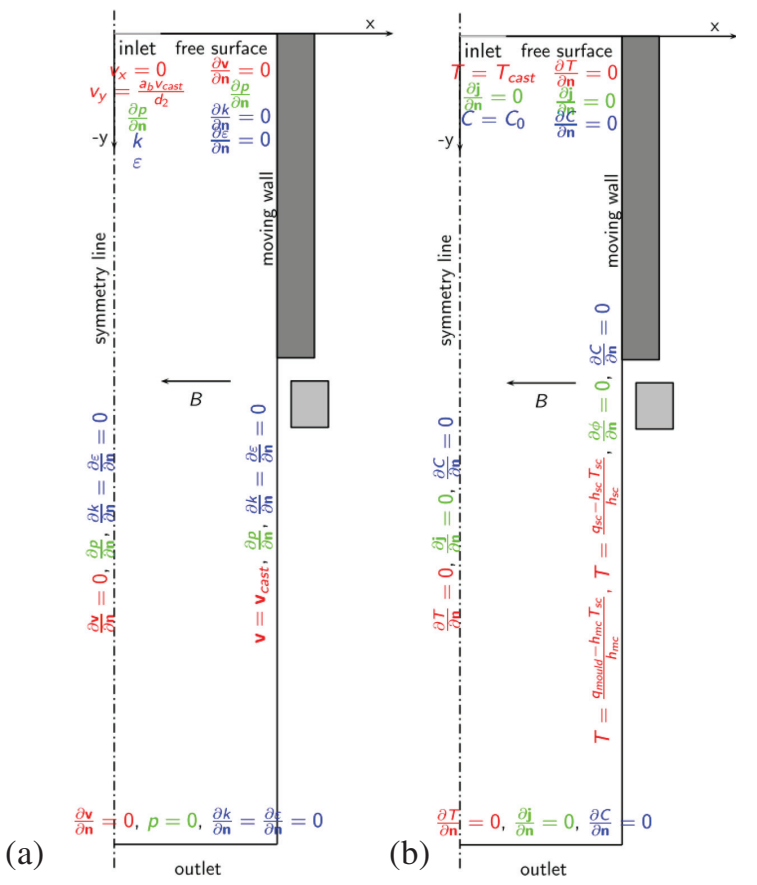

Figure 3: a) Boundary and initial conditions for velocity, pressure, turbulent kinetic energy and dissipation rate, b) boundary and initial conditions for temperature, magnetic field and species concentration Slika 3: a) Robni in začetni pogoji za hitrost, tlak, turbulentno kinetično energijo in hitrost disipacije, b) robni in začetni pogoji za temperaturo, magnetno polje in koncentracijo

problem with continuous casting have been published in several articles. ${ }^{19-21}$

\subsection{EM field calculations}

The magnetic field for the EMBR is calculated analytically. The EMBR device consists of two coils, as shown in Figure 4. The magnetic fields in these coils can either face one another or point in a parallel direction, as shown in Figures 5 and $\mathbf{6}$. The magnetic field of both coil configurations is shown in Figures $\mathbf{7}$ and 8 . The parallel coil configuration is chosen, as this is the default configuration for EMBR. As the coils in the EMBR device have iron cores, the magnetic field is

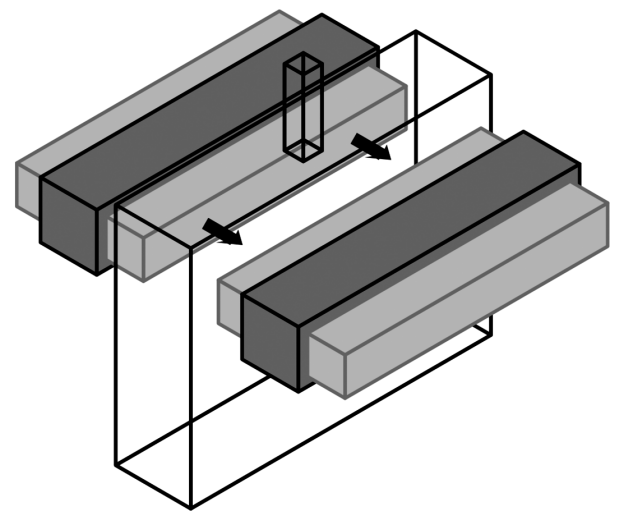

Figure 4: Scheme of EMBR

Slika 4: Shema EMBR

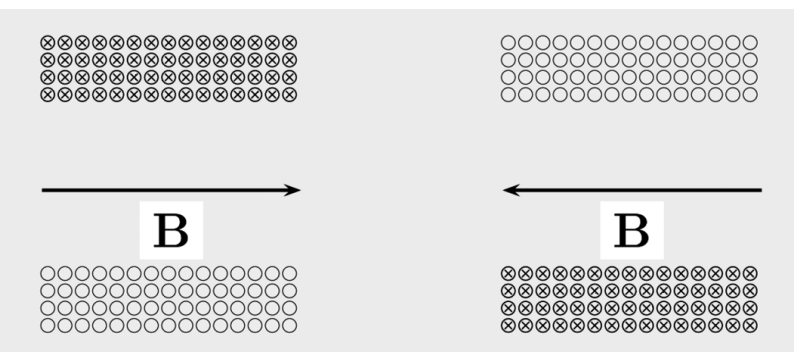

Figure 5: Scheme of the magnetic field for the coils facing each other Slika 5: Shema magnetnega polja tuljav, obrnjenih druga proti drugi

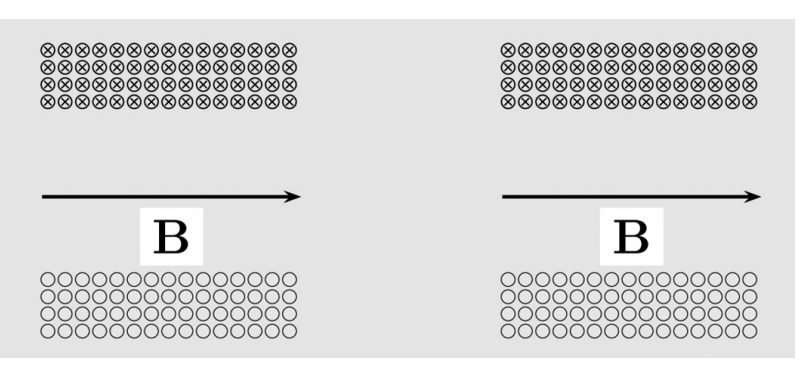

Figure 6: Scheme of the magnetic fields facing in the same direction Slika 6: Shema magnetnega polja tuljav, obrnjenih v enako smer

enhanced due to the magnetization, as shown in Figure 9.

In general, steel is ferromagnetic, and thus the possibility of the influence of magnetization needs to be checked. The operating temperature in the strand is well above the Curie temperature, where steel is paramagnetic. The magnetic field in the molten steel in the strand is therefore not further influenced by the external magnetic field. The temperature dependence of the permeability of molten steel is shown in Figure $\mathbf{1 0 .}$

The computational domain presents half of the longitudinal section of the billet, which is $1.8 \mathrm{~m}$ long and $14 \mathrm{~cm}$ wide. The SEN diameter is $3.5 \mathrm{~cm}$, the mold

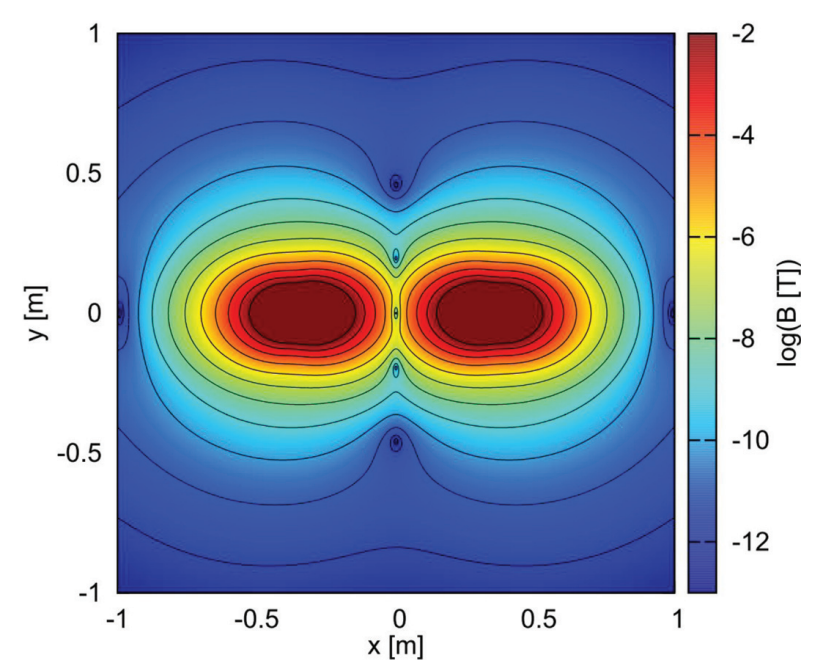

Figure 7: Magnetic field of coils facing each other

Slika 7: Magnetno polje tuljav, obrnjenih druga proti drugi 


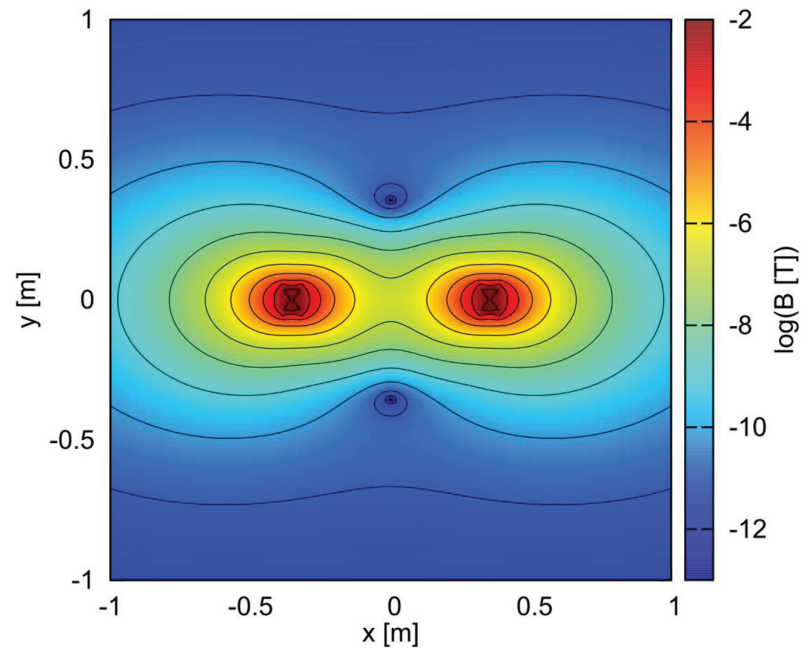

Figure 8: Magnetic field of coils facing in the same direction Slika 8: Magnetno polje tuljav, obrnjenih v enako smer

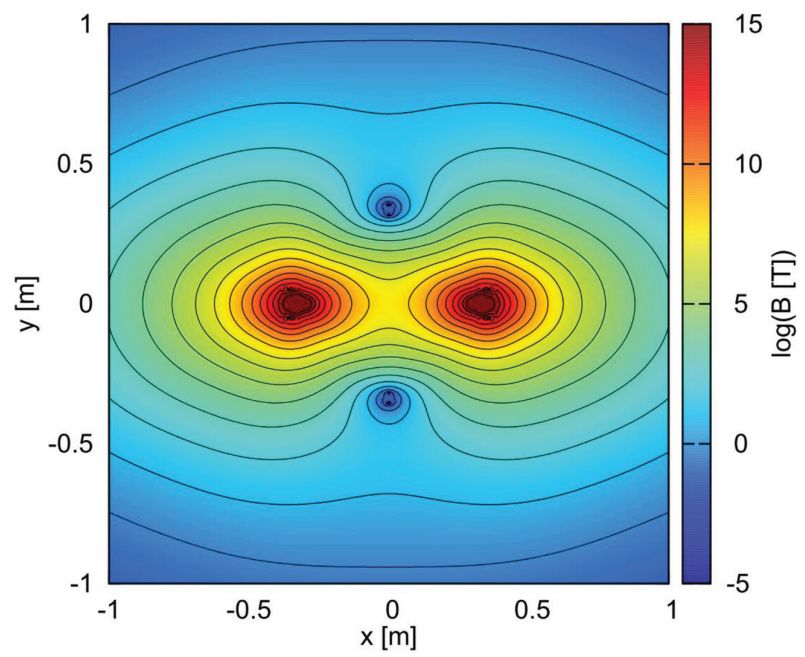

Figure 9: Magnetic field of parallel coils configuration (coils facing in the same direction) with an iron core

Slika 9: Magnetno polje paralelne postavitve tuljav (tuljave obrnjene v enako smer) z železnim jedrom

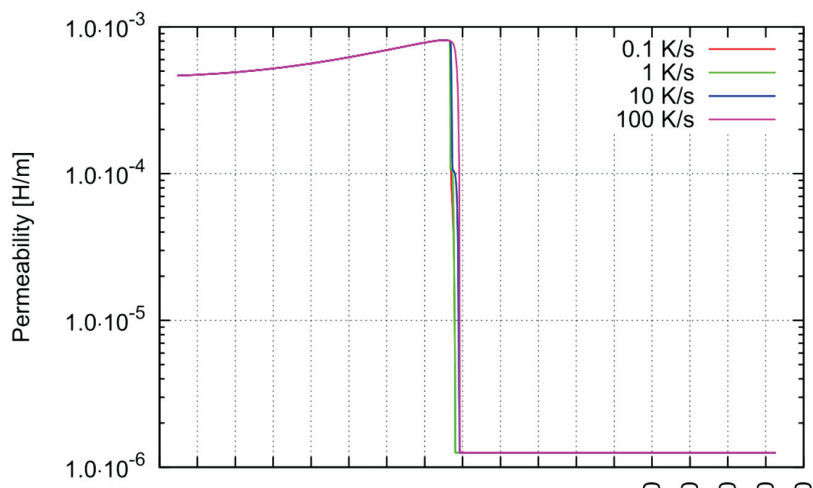

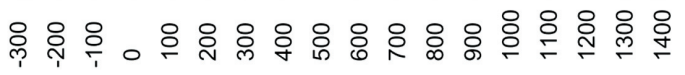

Temperature $[\mathrm{K}]$

Figure 10: Temperature dependence of permeability for steel Slika 10: Temperaturna odvisnost permeabilnosti jekla height is $0.8 \mathrm{~m}$ and the coil height is $10 \mathrm{~cm}$. The magnetic field is calculated for a coil configuration with 11 windings in the $y$ direction and 25 windings in the $x$ direction for coils placed $0.05 \mathrm{~m}$ away from the strand. The coils are placed just below the mold. A direct current with an amplitude of 50 A runs through the coils. Normally, the material properties of steel are temperature dependent. However, for the purpose of this simplified model, constant values are used for each of the phases. The values are given in Table $\mathbf{1}$.

Table 1: Material properties of steel

Tabela 1: Snovne lastnosti jekla

\begin{tabular}{|c|c|}
\hline property & value \\
\hline$\rho$ & $7200 \mathrm{~kg} / \mathrm{m}^{3}$ \\
\hline$\lambda$ & $30 \mathrm{~W} /(\mathrm{m} \mathrm{K})$ \\
\hline$c_{\mathrm{p}}$ & $700 \mathrm{~J} /(\mathrm{kg} \mathrm{K})$ \\
\hline$T_{\mathrm{S}}$ & $1680 \mathrm{~K}$ \\
\hline$T_{\mathrm{L}}$ & $1760 \mathrm{~K}$ \\
\hline$h_{\mathrm{m}}$ & $250000 \mathrm{~J} / \mathrm{kg}$ \\
\hline$\mu$ & $0.006 \mathrm{~Pa} \mathrm{~s}$ \\
\hline$\beta_{\mathrm{T}}$ & $1 \cdot 10^{-4} 1 / \mathrm{K}$ \\
\hline$\beta_{\mathrm{C}}$ & $4 \cdot 10^{-3} 1 / \%$ \\
\hline$K_{0}$ & $6.25 \cdot 10^{9} \mathrm{~m}^{-1}$ \\
\hline$C_{\mathrm{ref}}$ & 0.008 \\
\hline$D_{\mathrm{S}}$ & $1.6 \cdot 10^{-11} \mathrm{~m}^{2} / \mathrm{s}$ \\
\hline$D_{\mathrm{L}}$ & $1.0 \cdot 10^{-8} \mathrm{~m}^{2} / \mathrm{s}$ \\
\hline$\sigma$ & $0.59 \cdot 10^{6} /(\Omega \mathrm{m})$ \\
\hline
\end{tabular}
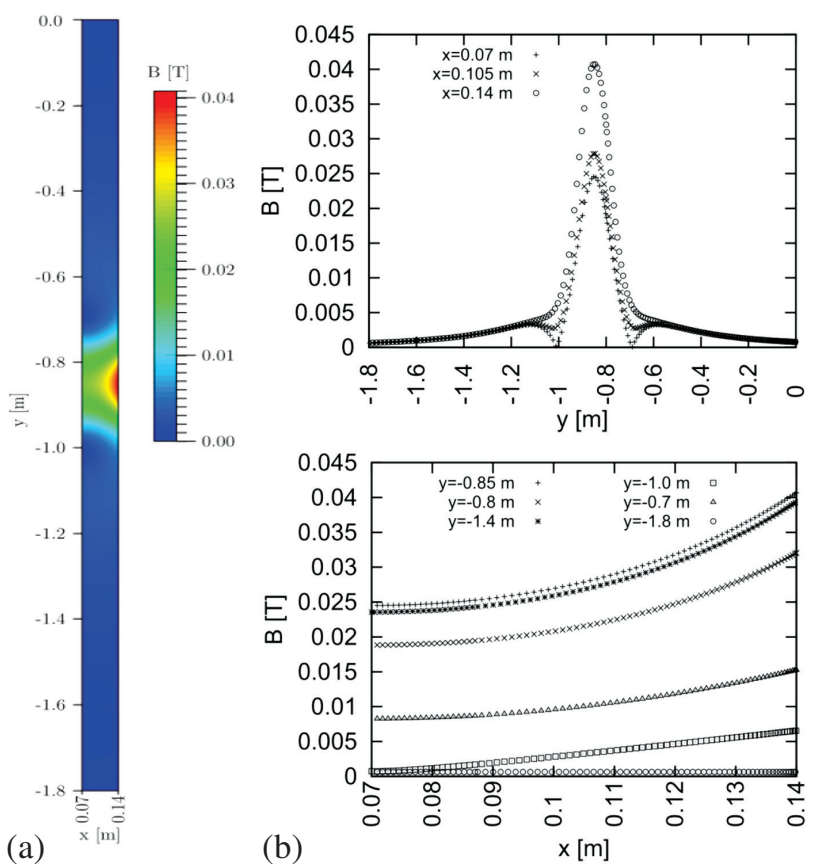

Figure 11: Magnetic field of parallel coils configuration with iron core: a) contour plot, b) top: vertical cross-section of the magnetic field at $0.07 \mathrm{~m}, 0.125 \mathrm{~m}$ and $0.14 \mathrm{~m}, \mathrm{~b}$ ) bottom: horizontal cross-sections at $-0.7 \mathrm{~m},-0.8 \mathrm{~m},-0.85 \mathrm{~m},-1.0 \mathrm{~m},-1.4 \mathrm{~m}$ and $-1.8 \mathrm{~m}$

Slika 11: Magnetno polje paralelne postavitve tuljav z železnim jedrom: a) konture magnetnega polja, b) zgoraj: navpični prerez magnetnega polja pri $0,07 \mathrm{~m}, 0,125 \mathrm{~m}$ in $0,14 \mathrm{~m}, \mathrm{~b}$ ) spodaj: vodoravni prerez magnetnega polja pri $-0,7 \mathrm{~m},-0,8 \mathrm{~m},-0,85 \mathrm{~m},-1,0 \mathrm{~m},-1,4 \mathrm{~m}$ in $-1,8 \mathrm{~m}$ 


\subsection{EMBR for the continuous casting of steel}

First the magnetic field in the strand for a default coil configuration with 25 windings in the $x$ direction, 11 windings in the $y$ direction, an electric current of $50 \mathrm{~A}$, and a span distance of $0.05 \mathrm{~m}$ is calculated. The results are shown in Figure 11. The effect of this magnetic field is then investigated for the velocity, temperature and concentration fields. To better present the effect of the magnetic field the results are compared to the example without a magnetic field, as can be seen in Figures $\mathbf{1 2}$ to 14.

The effect of magnetic field on temperature is shown in Figure 12. The application of EMBR to the continuous casting of steels lowers the temperature throughout the mold. The lowering of the temperatures is the most apparent in the mold region.

In Figure 13 a contour plot of the velocity field is shown together with several representative, both vertical and horizontal, cross-sections. The calculations confirm that the application of a magnetic field affects the velocity field. In the case of a parallel coil arrangement of the EMBR, the magnetic field slows down the velocity and diminishes the recirculation zones.

Finally, the effect of applying the EMBR to the continuous casting of steel is investigated for the concentration field. The results of the calculations are shown in Figure 14, from which it can be confirmed that the
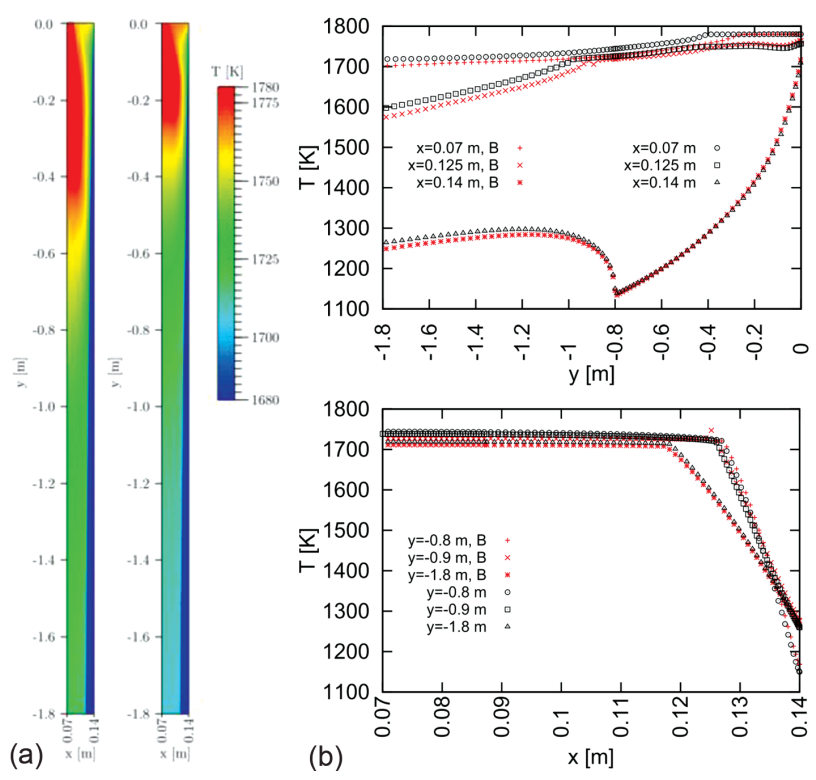

Figure 12: a) The velocity contour plots for configuration without (left) and with (right) a magnetic field, b) top: comparison of vertical cross-sections for velocities with and without magnetic field at 0.07 $\mathrm{m}, 0.125 \mathrm{~m}$ and $0.14 \mathrm{~m}, \mathrm{~b})$ bottom: comparison of horizontal cross-sections for velocities with and without magnetic field at $0.8 \mathrm{~m}$, $0.9 \mathrm{~m}$ and $1.8 \mathrm{~m}$

Slika 12: a) Konture hitrostnega polja za konfiguracijo z magnetnim poljem (levo) in brez njega (desno), b) zgoraj: primerjava navpičnih prerezov hitrosti $\mathrm{z}$ magnetnim poljem in brez njega pri $0,07 \mathrm{~m}, 0,125$ $\mathrm{m}$ in $0,14 \mathrm{~m}, \mathrm{~b}$ ) spodaj: primerjava vodoravnih prerezov hitrosti $\mathrm{z}$ magnetnim poljem in brez njega pri $0,8 \mathrm{~m}, 0,9 \mathrm{~m}$ in $1,8 \mathrm{~m}$
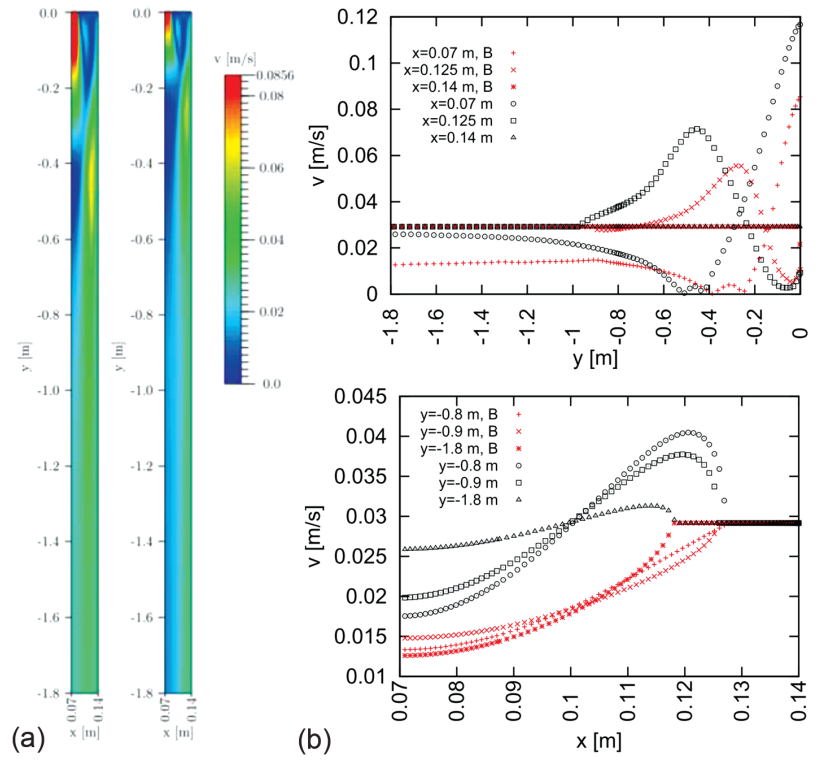

Figure 13: a) The temperature contour plots for configuration without (left) and with (right) magnetic field, b) top: comparison of vertical cross-sections for temperatures with and without magnetic field at $0.07 \mathrm{~m}, 0.125 \mathrm{~m}$ and $0.14 \mathrm{~m}, \mathrm{~b}$ ) bottom: comparison of horizontal cross-sections for temperatures with and without magnetic field at 0.8 $\mathrm{m}, 0.9 \mathrm{~m}$ and $1.8 \mathrm{~m}$

Slika 13: a) Konture temperaturnega polja za konfiguracijo z magnetnim poljem (levo) in brez njega (desno), b) zgoraj: primerjava navpičnih prerezov temperature $\mathrm{z}$ magnetnim poljem in brez njega pri $0,07 \mathrm{~m}, 0,125 \mathrm{~m}$ in $0,14 \mathrm{~m}$, b) spodaj: primerjava vodoravnih prerezov temperature $\mathrm{z}$ magnetnim poljem in brez njega pri $0,8 \mathrm{~m}, 0,9 \mathrm{~m}$ in 1,8
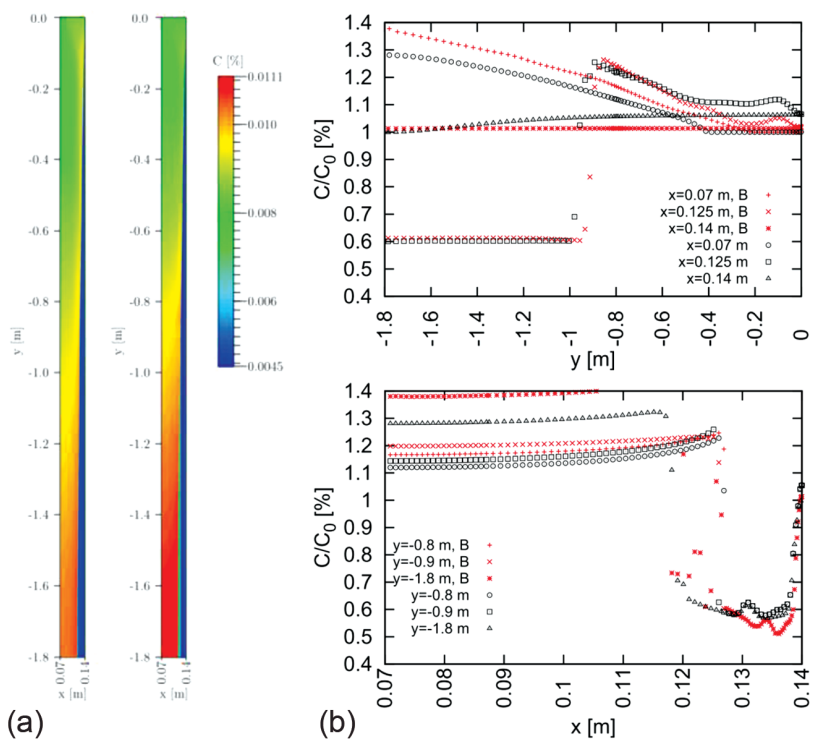

Figure 14: a) The concentration contour plots for configuration without (left) and with (right) magnetic field, b) top: comparison of vertical cross-sections for concentration with and without magnetic field at $0.07 \mathrm{~m}, 0.125 \mathrm{~m}$ and $0.14 \mathrm{~m}, \mathrm{~b}$ ) bottom: comparison of horizontal cross-sections for concentration with and without magnetic field at $0.8 \mathrm{~m}, 0.9 \mathrm{~m}$ and $1.8 \mathrm{~m}$

Slika 14: a) Konture koncentracijskega polja za konfiguracijo z magnetnim poljem (levo) in brez njega (desno), b) zgoraj: primerjava navpičnih prerezov koncentracije $\mathrm{z}$ magnetnim poljem in brez njega pri $0,07 \mathrm{~m}, 0,125 \mathrm{~m}$ in $0,14 \mathrm{~m}$, b) spodaj: primerjava vodoravnih prerezov koncentracije $\mathrm{z}$ magnetnim poljem in brez njega pri $0,8 \mathrm{~m}$, $0,9 \mathrm{~m}$ in $1,8 \mathrm{~m}$ 
magnetic field affects the concentration. In present case, the binary mixture of carbon and iron is investigated for the mass fraction $0.08 \%$ of carbon. It is shown that the magnetic field affects the pattern of the segregation in such a way that the levels of carbon are slightly decreased in the outer layers of the strand and increased in the middle of the strand.

\section{CONCLUSIONS}

In this paper, numerical calculations for electromagnetic braking in the continuous casting of steel are presented. The results, calculated with LRBFCM method, confirm that the application of a magnetic field affects the velocity of the fluid flow, as well as the temperature and species concentration. The present configuration of the coils produces a magnetic field that effectively slows down the velocity of the flow and decreases the temperature. It also affects the pattern of segregation in such a way that the concentration of carbon is decreased in the middle of the strand. In the future, an alternating magnetic field will be applied in order to calculate the electromagnetic stirring.

\section{Acknowledgements}

The research in this paper was sponsored by Centre of Excellence for Biosensors, Instrumentation and Process Control (COBIK) and Slovenian Grant Agency under Programme group P2-0357: Modelling and Simulation of Materials and Processes and applied project L2-6775 Modelling of Industrial Solidification Systems under Influence of Electromagnetic Field. This paper forms a part of the doctoral study of the first author that is partly co-financed by the European Union and by the European Social Fund respectively. The co-financing is carried out within the Human resources development operational programme for years 2007-2013, 1. Developmental priorities: Encouraging entrepreneurship and adaptation; Preferential directives 1.3: Scholarship schemes.

\section{REFERENCES}

${ }^{1}$ W. R. Irwing, Continuous Casting of Steel, The Institute of Materials, London 1993

${ }^{2}$ Steel Statistical Yearbook 2013, World Steel Association, Brussels 2013

${ }^{3}$ H. K. Versteeg, An Introduction to Computational Fluid Dynamics: the Finite Volume Method, Pearson Education, India 1995

${ }^{4}$ B. Zhao, B. G. Thomas, S. P. Vanka, R. J. O'Malley, Metallurgical and Materials Transactions B, 36 (2005) 6, 801-823, doi:10.1007/ s11663-005-0083-3

${ }^{5}$ M. R. Aboutalebi, M. Hasan, R. I. L. Guthrie, Metallurgical and Materials Transactions B, 26 (1995) 4, 731-744, doi:10.1007/ bf02651719

${ }^{6}$ D. S. Kim, W. S. Kim, K. H. Cho, Iron and Steel Institute of Japan International, 40 (2000) 7, 670-676, doi:10.2355/isijinternational. 40.670

${ }^{7}$ K. G. Kang, H. S. Ryou, N. K. Hur, Numer. Heat Tr. A, 48 (2005) 5, 461-481, doi:10.1080/10407780590911639

${ }^{8}$ N. Kubo, T. Ishii, J. Kubota, T. Ikagawa, Iron and Steel Institute of Japan International, 44 (2004) 3, 556-564, doi:10.2355/isijinternational.44.556

${ }^{9}$ C. H. Moon, S. M. Hwang, International Journal for Numerical Methods In Engineering, 57 (2003), 315-339, doi:10.1002/nme.679

${ }^{10}$ B. Šarler, R. Vertnik, Computers and Mathematics with Applications, 51 (2006), 1269-1282, doi:10.1016/j.camwa.2006.04.013

${ }^{11}$ D. C. Wilcox, Turbulence modeling for CFD, DCW Industries, Inc., California 1993

${ }^{12}$ W. D. Bennon, F. P. Incropera, Numerical Heat Transfer Part A-Applications, 13 (1988) 3, 277-296, doi:10.1080/104077888089 13614

${ }^{13}$ K. Abe, T. Kondoh, Y. Nagano, International Journal of Heat and Mass Transfer, 37 (1994), 139-151, doi:10.1016/0017-9310(94) 90168-6

${ }^{14}$ B. Šarler, R. Vertnik, K. Mramor, IOP Conference Series: Materials Science and Engineering, 33 (2012), 12012-12021, doi:10.1088/ $1757-899 \mathrm{x} / 33 / 1 / 012012$

${ }^{15}$ A. Chorin, Mathematical Computation, 22 (1968), 745-762

${ }^{16}$ M. D. Buchmann, Radial Basis Function: Theory and Implementations, Cambridge University Press, Cambridge 2003, doi:10.1017/ cbo9780511543241

${ }^{17}$ R. Franke, Mathematics of Computation, 38 (1982), 181-200, doi:10.1090/s0025-5718-1982-0637296-4

${ }^{18}$ K. Mramor, R. Vertnik, B. Šarler, Computer Modeling in Engineering \& Science, 92 (2013) 4, 327-352, doi:10.3970/cmes.2013. 092.327

${ }^{19}$ K. Mramor, Modelling of Continuous Casting of Steel under the Influence of Electromagnetic Field with Meshless Method, dissertation, UNG, Nova Gorica, 2014, p. 244

${ }^{20}$ K. Mramor, R. Vertnik, B. Šarler, Engineering Analysis with Boundary Elements, 49 (2014), 37-47, doi:10.1016/j.enganabound. 2014.04.013

${ }^{21}$ K. Mramor, R. Vertnik, B. Šarler, Mater. Tehnol., 48 (2014) 2, 281-288 